\title{
EFFECTS OF LIVE YEAST (Saccharomyces cerevisiae) SUPPLEMENTATION ON NUTRIENT DIGESTIBILITY, RUMEN FERMENTATION AND RUMEN MICROBIAL POPULATION COUNT IN SHEEP
}

\author{
M. M. Farghaly ${ }^{1}$ and H. A. Hamdon ${ }^{2}$ \\ 1- Department of Animal Production, Faculty of Agriculture, Assiut University, Assiut, Egypt, 2- Department of \\ Animal Production, Faculty of Agriculture, Assiut University, New Valley Branch, Egypt
}

Received: 16/11/2017

SUMMARY

This study investigated the impacts of dietary yeast culture (Saccharomyces cerevisiae) supplementation on rumen fermentation, nutrient digestibility and rumen microbial population in sheep. Three digestibility trials were carried out using fifteen Sohagi rams randomly assigned into three groups (5 rams/ each). Each trial lasted for three weeks, the firsttwo weekswere considered as a preliminary period followed by one week collection period.The groups were a control group fed basal diet without yeast supplement and treated groups fed either 0.5 (T1) or 1\% (T2) yeast culture (YC) mixed with concentrate diet. All animals were fed $60 \%$ of their requirements as concentrate mixture while, chopped corn stover was given as roughages ad libitum. The results pointed out, the digestibility of dry matter, organic matter, crude protein, crude fibre, neutral detergent fibre and hemicellulose were significantly $(P<0.05)$ improvedfor yeast treated diets compared with basal diet.Live yeast culture either 0.5 or $1 \%$ in concentrate diet increased $(P<0.05)$ the $p H$,volatile fatty acids $(V F A s)$, acetate and propionate, while rumen ammonia nitrogen on centration was decreased $(P<0.05)$. Live yeast supplementation $(0.5$ or $1 \%)$ improved $(P<0.05) N$ retention. The rumenal bacterial and protozoal counts increased $(P<0.05)$ due to YC supplementation. In conclusion, dietary live yeast culture ( $S$. cerevisiae) particular $1 \%$ of concentrate mixture may improve nutrient digestibility, fermentation patterns and rumen microbial population.

\section{Keywords: Sheep, live yeast, nutrients digestibility, rumen fermentation parameters}

\section{INTRODUCTION}

Fattening lambs demand diets with high concentrate ratio for increasing its growth performance (Mungoi et al., 2012). However, a highly concentrated diet tended to increase rumenal acidosis (Gonzalez-Momita et al., 2009). Supplementation of yeast to rumenant rations modified rumenal $\mathrm{pH}$, consequently reduced the adverse effects of high-concentrate diet (Calsamiglia et al. (2012). In fact, high rumenal $\mathrm{pH}$ due to Saccharomyces cerevisiae supplemented to diets, increased numbers of cellulolytic bacteria, like Fibrobacter succinogenes and Rumenococcus albus, which raised rate of rumenal fiber digestion (Callaway and Martin, 1997),modified volatile fatty acids concentrations, moreover it increased $\mathrm{pH}$ and increasing quantity, of lactate utilizing bacteria, particularly Selenomonas rumenantium and Meganosphera elsdenii then decreased lactate accumulation in the rumen (Callaway and Martin, 1997).

Yeast supplementation enhances the release of energy in the rumen to be more accessible for growing microorganisms and provides nutrients and/or soluble growth factors for more rumenal flora (Brossard et al., 2006). The advantages of yeast culture supplement were changing rumenal fermentation, improved bacterial activity, and increased rumen ciliates, which enhance degradability of forages and stream of microbial protein from the rumen (Wallace and Newbold, 1992). In Egypt live yeast is considerd one of the cheapest feed additives that added to sheep rations to improve animal performance and rumen parameters.

Literature about the effect of live yeast culture on rumen parameters and rumen protozoal and microbial count is conflicting, therefore this study investigate the impact of adding YC ( $S$. cerevisiae)at graded levels to sheep rations on nutrients digestibility, rumen fermentation parameters and total bacterial and protozoal count in the rumen.

\section{MATERIALS AND METHODS}

The experiment was carried out at the Animal Production Research Farm, Faculty of Agriculture, Sohag University and Animal Production Department, Faculty of Agriculture, Assiut University.

\section{Digestibility trials:}

The digestibility trials were carried out using fifteen rams (two years old and about $50 \pm 1.25 \mathrm{~kg}$ body weight). Each trial lasted for 3 weeks, the first 2 weeks were considered as a preliminary period followed byone week collection period. Animals were classified into three groups. The control group fed a basal diet consisting of roughage and concentrate mixture, but the two treated groups fed the basal diet supplemented with either $0.5 \%$ (T1) or $1 \%$ (T2) of yeast culture to concentrate mixture. The yeast culture used in this experiment was 
manufactured by F.L. Emmert., Co. USA. The animal's requirements for crude protein $(\mathrm{CP})$ and total digestible nutrients (TDN) were calculated according to NRC (1985). All animals of the three groups were fed $60 \%$ of their requirements as concentrate mixture while roughage was given ad libitum as chopped corn stover. Animals had free access to water. The rams were housed individually in metabolism cages.

\section{Chemical analysis and digestion coefficients measurements:}

The diet samples were taken daily during the collection period and the samples were mixed at the end of each trial, ground through $1 \mathrm{ml}$ screen for chemical analysis. Faeces were collected daily and $10 \%$ of its weight were taken and dried at $60-70{ }^{\circ} \mathrm{C}$ for $24 \mathrm{~h}$. The fecal samples from each animal were composited and grounded through a $1 \mathrm{~mm}$ mill screen for subsequent chemical analysis.

The chemical analysis of feeds residual and faeces were carried out using procedures of Association of the Official Analytical Chemists (AOAC, 1990). Neutral detergent fiber (NDF), Acid detergent fiber (ADF) and Acid detergent lignin (ADL) were determined using procedures of Goering and Van Soest (1970). The hemicellulose was calculated by the difference between NDF and ADF, while the cellulose was calculated by the difference between ADF and ADL. The apparent digestion coefficients of nutrients were calculated by expressing the difference between the content of nutrient in both consumed feed and faeces as a percentage of its intake. Chemical compositions of control, YC treated diets and corn stover are shown in Table (1).

Table 1. Chemical composition of experimental diets as dry matter basis (\%)

\begin{tabular}{lcccc}
\hline Items & \multicolumn{3}{c}{ Concentration mixture ${ }^{*}$} & \multirow{2}{*}{ Corn stover } \\
\cline { 2 - 4 } & Control & T1 & T2 & \\
\hline DM & 90.82 & 89.76 & 89.24 & 91.87 \\
OM & 80.24 & 79.04 & 78.42 & 83.78 \\
Ash & 10.58 & 10.72 & 10.82 & 8.09 \\
CP & 19.07 & 20.54 & 20.69 & 6.63 \\
CF & 15.02 & 14.87 & 15.42 & 32.25 \\
EE & 1.83 & 2.42 & 2.06 & 1.48 \\
NFE & 53.50 & 51.46 & 51.00 & 51.55 \\
NDF & 31.87 & 31.22 & 30.22 & 64.74 \\
ADF & 14.89 & 15.17 & 15.02 & 32.33 \\
ADL & 5.01 & 4.95 & 5.01 & 6.25 \\
Cellulose & 9.88 & 10.22 & 10.01 & 26.08 \\
Hemicellulose & 16.98 & 16.05 & 15.20 & 32.41 \\
\hline
\end{tabular}

* The ingredients of concentrate mixture were: $20 \%$ corticated cotton seed meal, $25 \%$ wheat bran, $37 \%$ yellow corn, $12 \%$ soybean meal, $3 \%$ vinasse, $2 \%$ limestone, $1 \%$ salt.

T1: $0.5 \%$ dry yeast culture diet, T2: $1 \%$ dry yeast culture diet

$\mathrm{DM}$, dry matter; $\mathrm{OM}$, organic matter; $\mathrm{CP}$, crude protein; $\mathrm{CF}$, Crude fiber; EE, ether extract; NFE, Nitrogen free extract; $\mathrm{NDF}$, Neutral detergent fiber; ADF, acid detergent fiber; ADL, acid detergent lignin

\section{Rumen liquor parameters:}

Rumen content samples were collected one time from each ram using a stomach tube on the next day after collection period of each digestibility trial. Samples were taken after $4 \mathrm{hrs}$ of feeding. Rumen liquor samples were divided into two parts, the first part filtrated through one layer of cheesecloth, which used to measure protozoal and bacterial count. However, the second one filtrates through four layers of cheesecloth. The filtrate portion was used immediately for measurement of $\mathrm{pH}$ using a digital $\mathrm{pH}$ meter and ammonia concentration according to Conway (1962) method. Few drops of saturated solution of mercuric chloride were added to the filtrate portion to stop microbial activity before they were stored for analysis (Tabana, 1994), then samples were kept frozen $\left(-20^{\circ} \mathrm{C}\right)$ for subsequent determination oftotalshort chain fatty acids (VFAs). Theshort chain fatty acids (VFAs) measured using gas chromatography (GC) analyses Carlo Erba 5000 model (Carlo Erba, Milan, Italy). The samples of
VFAs measure were prepared as described by Kroismayr and Sehm (2007).The total protozoal count was conducted according to Abou El-Naga (1967). The total rumen bacterial numbers were determined using the method performed by Newbold et al. (1995).

\section{Statistical analysis:}

Statistical analysis was done according to general linear model (G.L.M) of S.A.S program (2001), version 8.2. Differences between groups for nutrient digestibility, feeding value, nitrogen balance, total bacterial and protozoal count and rumen liquor parameters were evaluated by one-way ANOVA. Duncan Multiple Range Test (Steel and Torrie, 1980)was used to test the effect of treatments. The data were presented as mean \pm S.E.M. Level of significance was set at $\mathrm{P}<0.05$. The statistical model was as follows.

$\mathrm{Y}_{\mathrm{ij}}=\mu+\mathrm{T}_{\mathrm{i}}+\mathrm{e}_{\mathrm{ij}}$ 
Egyptian J. Anim. Prod. (2018)

Where: $\mathrm{Y}_{\mathrm{ij}}=$ the observation $\mathrm{ij}, \mu=$ the overall mean, $\mathrm{T}_{\mathrm{i}}=$ the effect due to treatment $\mathrm{i} ., \mathrm{e}_{\mathrm{ij}}=$ the experimental error.

\section{RESULTS AND DISCUSSION}

\section{Nutrient digestibility:}

The nutrients digestibilitys of treated diets in the rumen are shown in Table 2. The dry matter (DM), organic matter and hemicellulose were improved $(\mathrm{P}<0.05)$ for rams supplemented with 0.5 and $1 \%$ yeast culture compared with control group. Likewise, dietary supplement of $1 \%$ YC had significant $(\mathrm{P}<0.05)$ effect on $\mathrm{CP}, \mathrm{CF}$ and NDF digestibility in rams as compared with those fed diet supplemented with $0.5 \%$ YC or diet with no supplement(control) groups. Newbold et al. (2000) found that dietary yeast increased the breakdown of fiber in the rumen, which increased microbial protein production, consequently, more protein available for absorption in the small intestine. Ghazanfar et al. (2015) attributed the improvement in nutrients digestibility to the increase of cellulose degrading microbial biomass population inside rumen. The improved CP digestibility by $\mathrm{YC}$ supplementation is confirmed with the findings of Chaucheyras- Durand et al. (2005)who reported that live yeast decreased the rate of peptides degradation, which lowering ammonia wastage and consequently increased the amount of rumen undegraded protein available to rams. Dietary yeasts improved growing conditions for the anaerobic rumen microbes, especially the cellulolytics through scavenging available oxygen from the surfaces of freshly ingested feeds to maintain metabolic activity and decreasing redox potential in the rumen (Chaucheyras-Durand et al., 2008).

Table 2. Effect of yeast culture supplement to rams rations on nutrient digestibility

\begin{tabular}{|c|c|c|c|c|}
\hline \multirow{2}{*}{ Item } & \multicolumn{3}{|c|}{ Treatment } & \multirow{2}{*}{ P-value } \\
\hline & Control & $\mathrm{T} 1$ & $\mathrm{~T} 2$ & \\
\hline $\mathrm{DM}$ & $68.30^{b} \pm 0.70$ & $71.83^{a} \pm 0.94$ & $73.08^{a} \pm 0.92$ & 0.018 \\
\hline OM & $68.24^{b} \pm 1.10$ & $73.00^{\mathrm{a}} \pm 0.64$ & $72.01^{\mathrm{ab}} \pm 1.55$ & 0.059 \\
\hline $\mathrm{CP}$ & $68.25^{b} \pm 1.09$ & $67.97^{b} \pm 0.94$ & $72.78^{a} \pm 0.25$ & 0.012 \\
\hline $\mathrm{CF}$ & $48.03^{b} \pm 0.98$ & $50.41^{b} \pm 0.96$ & $56.21^{\mathrm{a}} \pm 1.19$ & 0.003 \\
\hline $\mathrm{EE}$ & $85.13 \pm 0.57$ & $85.03 \pm 1.50$ & $84.95 \pm 0.93$ & 0.993 \\
\hline NFE & $76.41^{b} \pm 0.55$ & $78.41^{\mathrm{ab}} \pm 0.64$ & $78.97^{\mathrm{a}} \pm 0.59$ & 0.051 \\
\hline NDF & $55.73^{b} \pm 0.16$ & $63.63^{\mathrm{b}} \pm 0.56$ & $65.41^{\mathrm{a}} \pm 0.86$ & 0.001 \\
\hline $\mathrm{ADF}$ & $44.94 \pm 1.18$ & $44.56 \pm 1.28$ & $46.63 \pm 0.83$ & 0.429 \\
\hline $\mathrm{ADL}$ & $6.18 \pm 0.16$ & $6.11 \pm 0.16$ & $5.71 \pm 0.39$ & 0.442 \\
\hline Cellulose & $38.76 \pm 1.10$ & $38.45 \pm 1.42$ & $40.91 \pm 1.01$ & 0.349 \\
\hline Hemicellulose & $10.79^{b} \pm 1.24$ & $19.06^{\mathrm{a}} \pm 0.92$ & $18.78^{a} \pm 0.67$ & 0.001 \\
\hline
\end{tabular}

${ }^{a, b}$ Means within the same raw in each item with different superscripts are significantly different $(\mathrm{P}<0.05)$.

T1: $0.5 \%$ yeast culture, T2: $1 \%$ yeast culture of concentrate mixture.

$\mathrm{DM}$, dry matter; OM, organic matter; CP, crude protein; CF, Crude fiber; EE, ether extract; NFE, Nitrogen free extract; NDF, Neutral detergent fiber; ADF, acid detergent fiber; ADL, acid detergent lignin

\section{Rumen parameters:}

As shown in Table 3, supplementation of yeast culture at the level of 0.5 and $1 \%$ of the concentrate diets increased $(\mathrm{P}<0.05)$ the $\mathrm{pH}$ values, concentrations of total VFAs, acetate and propionate as compared with the control diet. However, other VFAs and the ratio of acetate to propionate and rumenal concentrations of NH3-N were lower $(\mathrm{P}<0.05)$ for both levels of yeast culture than control one.The higher values of rumen $\mathrm{pH}$ in yeast treated groups may be due to yeast cells have the ability to motivate the efficiency of Selenomonas rumenantium and Megasphaera elsdenii to utilize lactic acid in the rumen (Rossi et al.2004) or may be $S$. cerevisiae can compete with other bacteria to utilize starch for fermentation (Lynch and Martin, 2002), leading to the inhibition of lactate accumulation in the rumen, thereby decreasing incidences of acidosis (Calsamiglia et al., 2012). The mean concentration of rumen ammonia nitrogen in the present study was lower in rams received two levels of $\mathrm{YC}$ than control one (Table 3). Similar results were found by Lu et al. (2016). The lowering concentration of $\mathrm{NH}_{3}-\mathrm{N}$ in the rumen may be related to more incorporation of $\mathrm{NH}_{3}$ $\mathrm{N}$ into microbial protein resulted in improvement in microbial activity (Erasmus et al., 1992).

The higher value of acetate and propionate production indicated an improvement of rumen energy metabolism efficiency and/or contributed to the enhanced rumenal fermentation (Malekkhahi et al., 2015).Tang et al. (2008)found that yeast product supplement affecting the growth of different species of rumen microbes and modification of VFA production and pattern. Similarly, Harrison et al. (1988)stated that the addition of yeast culture containing $S$. cerevisiae had decreased the acetate to propionate ratio in cow's rumen fluid. 
Table 3. Effect of live yeast cultural supplement on rumen parameters

\begin{tabular}{|c|c|c|c|c|}
\hline \multirow{2}{*}{ Item } & \multicolumn{3}{|c|}{ Treatment } & \multirow{2}{*}{ P-value } \\
\hline & Control & $\mathrm{T} 1$ & $\mathrm{~T} 2$ & \\
\hline $\mathrm{pH}$ & $6.13^{b} \pm 0.01$ & $6.35^{\mathrm{a}} \pm 0.02$ & $6.37^{\mathrm{a}} \pm 0.02$ & 0.001 \\
\hline Ammonia mg/L & $87.53^{\mathrm{a}} \pm 1.09$ & $79.60^{b} \pm 0.85$ & $75.74^{\mathrm{c}} \pm 0.82$ & 0.001 \\
\hline Гotal VFAs (m mole/L) & $146.07^{\mathrm{b}} \pm 0.95$ & $150.27^{\mathrm{a}} \pm 1.13$ & $153.40^{\mathrm{a}} \pm 1.16$ & 0.008 \\
\hline \multicolumn{5}{|l|}{ Relative proportion $\%$} \\
\hline Acetate & $61.94^{b} \pm 1.09$ & $64.30^{\mathrm{a}} \pm 0.49$ & $63.78^{a} \pm 0.32$ & 0.007 \\
\hline Propionate & $14.06^{\mathrm{b}} \pm 0.08$ & $16.57^{\mathrm{a}} \pm 0.29$ & $16.34^{\mathrm{a}} \pm 0.09$ & 0.001 \\
\hline n-Butyrate & $17.17^{\mathrm{a}} \pm 0.18$ & $14.13^{c} \pm 0.48$ & $15.49^{b} \pm 0.14$ & 0.001 \\
\hline Iso-Butyrate & $2.59^{\mathrm{a}} \pm 0.03$ & $1.57^{\mathrm{b}} \pm 0.12$ & $1.46^{\mathrm{b}} \pm 0.08$ & 0.001 \\
\hline n-Valerate & $1.77^{\mathrm{a}} \pm 0.03$ & $1.23^{\mathrm{c}} \pm 0.03$ & $1.52^{\mathrm{b}} \pm 0.07$ & 0.001 \\
\hline iso-Valerate & $2.43^{\mathrm{a}} \pm 0.05$ & $1.90^{\mathrm{ab}} \pm 0.30$ & $1.40^{\mathrm{b}} \pm 0.05$ & 0.017 \\
\hline Acetate/ Propionate & $4.40^{\mathrm{a}} \pm 0.02$ & $3.88^{\mathrm{b}} \pm 0.07$ & $3.90^{\mathrm{b}} \pm 0.07$ & 0.001 \\
\hline
\end{tabular}

\section{Feeding value and nitrogen balance:}

As clear in Table 4, the feeding values in terms of total digestible nutrients (TDN), starch value (SV) and digestible crude protein (DCP) as well as the $\mathrm{N}$ retained of diets supplemented with 0.5 or $1 \%$ yeast culture were higher $(\mathrm{P}<0.05)$ than those of control diet. Furthermore, the DCP value of $1 \% \mathrm{YC}$ supplement had higher $(\mathrm{P}<0.05)$ than DCP that of $0.5 \%$ YC treated one (Table 4$)$.

Results in Table (4) show that the $\mathrm{N}$ retention ofT2washigher $(\mathrm{P}<0.05)$ than that of control group.
However, no differences were found between T1 and T2 groups. Similar result was reported by Cole et al. (1992) and Malekkhahi et al. (2015). The higher retention of $\mathrm{N}$ in $\mathrm{YC}$ supplemented rams in the present study could explain the reduction of rumenal $\mathrm{NH}_{3}-\mathrm{N}$ concentration (Table3) due to increased $\mathrm{N}$ incorporation into microbial protein as a result of improved microbial activity (Paryad and Rashidi, 2009).

Table 4. Effect of yeast culture supplementation on feeding value, total microbial population and nitrogen balance

\begin{tabular}{|c|c|c|c|c|}
\hline \multirow{2}{*}{ Item } & \multicolumn{3}{|c|}{ Treatment } & \multirow{2}{*}{ P-Value } \\
\hline & Control & T1 & $\mathrm{T} 2$ & \\
\hline TDN & $60.20^{\mathrm{b}} \pm 0.48$ & $66.40^{\mathrm{a}} \pm 0.61$ & $66.63^{\mathrm{a}} \pm 0.78$ & 0.001 \\
\hline SV & $54.51^{\mathrm{b}} \pm 0.36$ & $60.94^{\mathrm{a}} \pm 1.48$ & $62.14^{\mathrm{a}} \pm 1.29$ & 0.005 \\
\hline $\mathrm{DCP}$ & $11.33^{\mathrm{c}} \pm 0.60$ & $13.88^{\mathrm{b}} \pm 0.71$ & $16.19^{\mathrm{a}} \pm 0.65$ & 0.005 \\
\hline Total viable bacteria, $\times 10^{8} / \mathrm{mL}$ & $1.66^{\mathrm{b}} \pm 0.04$ & $2.45^{\mathrm{a}} \pm 0.18$ & $2.72^{\mathrm{a}} \pm 0.09$ & 0.002 \\
\hline Total Protozoa, x $10^{6}$ & $3.07^{\mathrm{b}} \pm 0.10$ & $4.00^{\mathrm{a}} \pm 0.11$ & $4.07^{\mathrm{a}} \pm 0.10$ & 0.001 \\
\hline $\mathrm{N}$ intake (g/day) & $16.03^{b} \pm 0.77$ & $18.77^{\mathrm{a}} \pm 0.14$ & $19.26^{\mathrm{a}} \pm 0.51$ & 0.011 \\
\hline Fecal N (g/day) & $5.03 \pm 0.26$ & $5.55 \pm 0.32$ & $5.33 \pm 0.35$ & 0.542 \\
\hline Urinary N (g/day) & $4.71 \pm 0.23$ & $5.37 \pm 0.54$ & $4.87 \pm 0.43$ & 0.546 \\
\hline Retained N (g/day) & $6.28^{b} \pm 0.94$ & $7.85^{\mathrm{ab}} \pm 0.22$ & $9.06^{\mathrm{a}} \pm 0.43$ & 0.049 \\
\hline
\end{tabular}

\section{Rumen microbial population:}

The data presented in table (4) show that the total bacterial and protozoal count were higher $(\mathrm{P}<0.05)$ in the rumen of YC supplemented animals than those in the rumen of control one. However, such differences in supplement YC groups were not significant. The elevated number of bacteria and protozoa in the rumen of YC supplemented animals may be due to the yeast cells contains several vitamins, enzymes, organic acids and some unknown cofactors that may enhance growth of rumen microbes (Chaucheyras et al.,1995). The total count of rumen cellulolytic bacteria was increased with YC addition, particularly in high concentrate diets, causing more improvement on rumen fermentation and nutrient digestibility (Chaucheyras-Durand and Fonty, 2002). Similarly, Chaucheyras-Durand et al. (2005)reported that the number of cellulolytic bacteria and protozoa increased in newborn lambs supplemented with yeast culture by using stomach tube.

\section{CONCLUSION}

Supplement dietary live yeast culture $(S$. cerevisiae) particularly $1 \%$ of concentrate mixture to sheep diets may improve nutrients digestibility, 
Egyptian J. Anim. Prod. (2018)

fermentation patterns, rumen microbial population and protozoal count.

\section{REFERENCES}

Abou El-Naga MA., 1967. Some metabolic studies on rumen microorganisms. Ph.D. Thesis, Faculty of Agric., Univ. Alex, Egypt.

AOAC. 1990. Association of Official Analytical Chemists, Official Methods of Analysis. $15^{\text {th }}$ Edition. Washington, DC.

Brossard L, F. Chaucheyras-Durand, B. MichaletDoreauand, and C. Martin, 2006. Dose effect of live yeasts on rumen microbial communities and fermentation characteristics during butyric latent acidosis in sheep: new type interaction. Animal Sci, 82: 829- 836.

Callaway ES and SA.Martin, 1997. Effects of a Saccharomyces cerevisiae culture on rumenal bacteria that utilize lactate and digest cellulose. J. of Dairy Sci.,80: 2035-2044.

Calsamiglia S, M. Blanch, A. Ferret, D. Moya, 2012. Is sub-acute rumenal acidosis a $\mathrm{pH}$ related problem? Causes and tools for its control. Anim. Feed Sci. Technol, 172: 42-50.

Chaucheyras F, G. Fonty, G. Bertin and P. Gouet, 1995. In vitro $\mathrm{H}_{2}$ utilization by a rumenal acetogenic bacterium cultivated alone or in association with an archaea methanogen is stimulated by a probiotic strain of Saccharomyces cerevisiae. Applied Environ. Microbiol. 61: 34663467.

Chaucheyras-Durand F and G. Fonty, 2002. Influence of a probiotic yeast (Saccharomyces cerevisiae CNCM I-1077) on microbial colonization and fermentations in the rumen of newborn lambs. Micr. Ecol. Health Dis., 14:3036.

Chaucheyras-Durand F, S. Masseglia and G. Fonty, 2005. Effect of the microbial feed additive Saccharomyces cerevisiae CNCM I-1077 on protein and peptide degrading activities of rumen bacteria grown in vitro. Current Microbiology, 50: 96-101.

Chaucheyras-Durand F, ND. Walker and A. Bach, 2008. Effects of active dry yeasts on the rumen microbial ecosystem: Past, present and future. Anim. Feed Sci. Technol., 145: 5-26.

Cole, N A., CW. Purdy and DP. Hutcheson, 1992. Influence of yeast culture on feeder calves and lambs. J. of Anim. Sci. 70, 1682-1690.

Conway EJ. 1962. Microdefusion Analysis and Volumetric Error. (5 $5^{\text {th. }}$ Ed.) Crosby- Lockwood and Sons Ltd., London; 1962.

Erasmus LJ, PM. Botha and A. Kistner, 1992. Effect of yeast culture supplement in production, rumen fermentation and duodenal ritrogen flow in dairy cows.J. of Dairy Sci., 75: 3056-3061.
Ghazanfar S, MI. Anjum and AA. Ahmed, 2015. Effects of dietary supplementation of yeast (saccharomyces cerevisiae) culture on growth performance, blood parameters, nutrient digestibility and fecal flora of dairy heifers. J. Anim. Plant Sci. 25(1): 53-59.

Goering HK and PJ. Van Soest, 1970. Forage fiber analysis (apparatus, reagents, procedures and some application. Agriculture Research Service, USDA, Washington, DC; (Handbook No. 379).

Gonzalez-Momita M L, JR. Kawas, R. GarciaCastillo, C. Gonzalez-Morteo, J. Aguirro-Ortega, G. Hernandez-Vidal, H. Fimbres-Durazo, FJ. Pincon-Rubio and CD. Lu, 2009. Nutrient intake, digestibility, mastication and rumenal fermentation of Pelibuey lambs fed finishing diets with ionophore (monensinor lasalocid) and sodium malate. Small Rumenant Research , 83: $1-6$.

Harrison GA, RW. Hemken, KA. Dawson, RJ. Harmon and KB. Barker, 1988. Influence of addition of yeast culture supplement to diets of lactating cows on rumenal fermentation and microbial populations. J. Dairy Sci., 71: $2967-$ 2975.

Kroismayr A and J. Sehm, 2007. Effects of essential oils or Avilamycin on gut microbiology and blood parameters of weaned piglets. Bodenkultur , 59 (1-4): 111-120.

Lu Q, W. Jian, W. Min, Z. Chuanshe, H. Xuefeng, NO. Edwin, T. Zhiliang and T. Shaoxun, 2016. Effects of dietary addition of cellulase and a Saccharomyces cerevisiae fermentation product on nutrient digestibility, rumen fermentation and enteric methane emissions in growing goats. Archives of Animal Nutrition, 70 (3): 224-238.

Lynch HA and AS. Martin, 2002. Effects of Saccharomyces cerevisiae culture and Saccharomyces cerevisiae live cells on in vitro mixed rumenal microorganism fermentation. J. Dairy Sci.; 85: 2603-2608.

Malekkhahi M, AM. Tahmasbi, AA. Naserian, M. Danesh Mesgaran, JL. Kleen and AA. Parand, 2015. Effects of essential oils, yeast culture and malate on rumen fermentation, blood metabolites, growth performance and nutrient digestibility of Baluchi lambs fed high-concentrate diets. Journal of Animal Physiology and Animal Nutrition, 99: 221-229.

Mungoi M, C. Flores, R. Casals and G. Caja, 2012. Effect of malate and starch source on digestibility and nutrient balance of growing- fattening lambs. Animal Feed science and Technology; 22: 154162.

N.R.C. (1985): Nutrient Requirements of sheep. National Academy of Science. National Research Council, Washington, DC, U.S.A.

Newbold CJ, Rj. Wallace, XB. Chen and FM. Mclntosh (1995): Different strains of 
Saccharomyces cerevisiae differ in their effects on rumenal bacterial numbers in vitro and in sheep. J. Ainm. Sci., 73:1811-1818.

Newbold J. 2000. Manipulation of Rumen Fermentation- Yeast Culture. Paper presented at the IV International Seminar Applied Microbiology to Animal Nutrition in Querétaro, Mexico.

Paryad, A. and M. Rashidi, 2009. Effect of yeast (Saccharomyces cerevisiae) on apparent digestibility and nitrogen retention of tomato pomace in sheep. Pakistan Journal of Nutrition, 8: 273-278.

Rossi F, A. Di Luccia, DDA. Vincenti and PS. Cocconcelli, 2004. Effect of peptidic fractions from Saccharomyces cerevisiae culture on growth and metabolism of the rumenal bacteria Megasphaeraelsdenii. Animal Research ,53: 177186.
S.A.S. 2001. SAS/ STAT Guide for personal computer (version 8.2 End).SAS. INST., Cary, N.C; 1987.

Steel RG and JH. Torrie, 1980. "Principles and Procedures of Statistics" A Biometrical Approach (2 nd Ed) Mc Grow- Hill Book Co., New York.

Tabana ASA. 1994. Utilization of corn and sunflower plant residues in rumenant nutrition. M.Sc. Thesis, Fac. of Agric., Cairo. Univ., Egypt..

Tang SX, GO. Tayo, ZL.Tan, ZH. Sun, LX. Shen, CS. Zhou, WJ. Xiao, GP. Ren, XF. Han and SB. Shen, 2008. Effects of yeast culture and fibrolytic enzyme supplementation on in vitro fermentation characteristics of low-quality cereal straws. J Anim Sci., 86:1164-1172.

Wallace R J and CJ. Newbold, 1992. Probiotics for Rumenants. In: Probiotics: The Scientific Basis. R. Fuller, (Ed.). London: Chapman and Hall.

\section{تأثثير إضافة الخميرة الحية (Saccharomyces crevisiae) على هضم العناصر الغذائية، تخمرات الكرش و وعدد الكائنات الحية الاقيقة فى كرش الأغنام

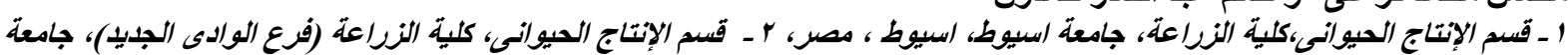

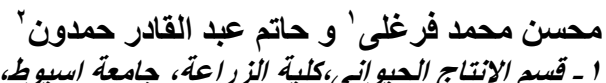

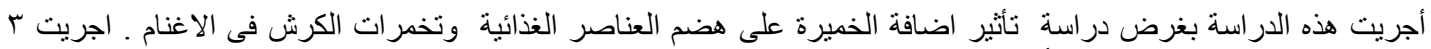

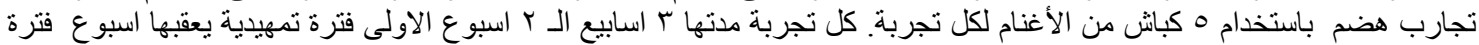

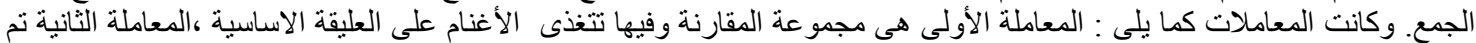

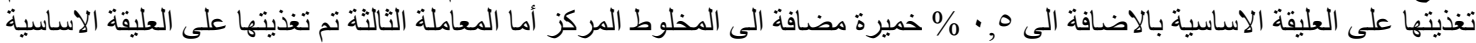

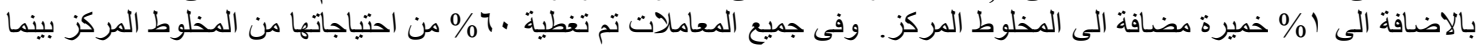

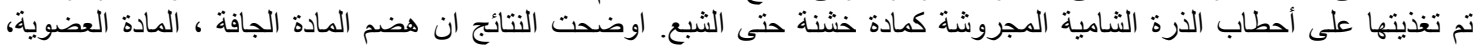

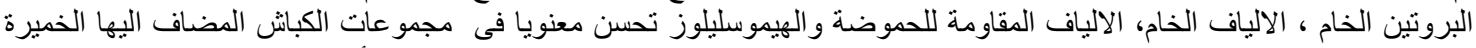

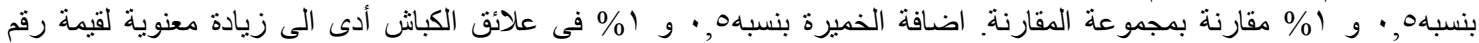

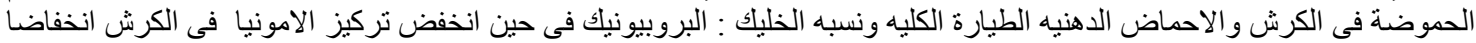

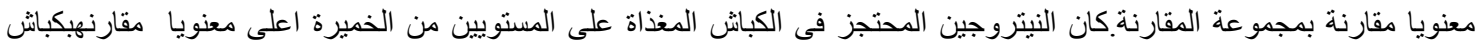

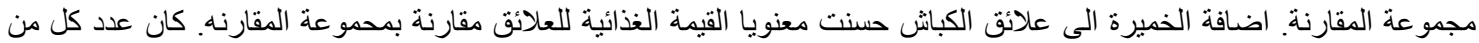

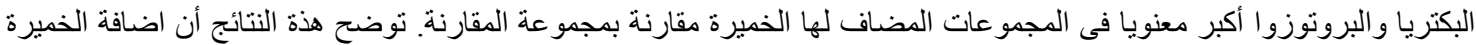

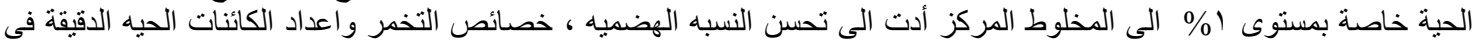
كرش اغنام التجربة. 